The Aesthetics of Antichrist 



\section{The Aesthetics of Antichrist}

From Christian Drama

to Christopher Marlowe

\section{JOHN PARKER}

Cornell University Press ithaca and London 
Cornell University Press gratefully acknowledges receipt of a subvention from Macalester College, which aided in the publication of this book.

\section{Copyright $\odot 2007$ by Cornell University}

All rights reserved. Except for brief quotations in a review, this book, or parts thereof, must not be reproduced in any form without permission in writing from the publisher. For information, address Cornell University Press, Sage House, 512 East State Street, Ithaca, New York 14850.

First published 2007 by Cornell University Press

Printed in the United States of America

\section{Library of Congress Cataloging-in-Publication Data}

Parker, John, 1972-

The aesthetics of Antichrist : from Christian drama to Christopher Marlowe / John Parker. p. $\mathrm{cm}$.

Includes bibliographical references and index. ISBN 978-0-8014-4519-4 (cloth : alk. paper)

1. Marlowe, Christopher, 1564-1593-Religion. 2. English drama-Early modern and Elizabethan, 1500-1600-History and criticism. 3. Christian drama, English-History and criticism. 4 Christianity and literature-England-History16th century. 5. Antichrist in literature. I. Title.

PR2677.R4P37 2007

822 '.3-dc22

2007018959

Cornell University Press strives to use environmentally responsible suppliers and materials to the fullest extent possible in the publishing of its books. Such materials include vegetable-based, low-VOC inks and acid-free papers that are recycled, totally chlorine-free, or partly composed of nonwood fibers. For further information, visit our website at www.cornellpress.cornell.edu.

Cloth printing 109876543321 